\title{
Correction to: Beyond Japanese NDC: energy and macroeconomic transitions towards 2050 in emission pathways with multiple ambition levels
}

\author{
Diego Silva Herran ${ }^{1,2}$ (D) Shinichiro Fujimori ${ }^{1,3,4}$
}

Published online: 5 November 2021

(c) The Author(s) 2021

\section{Correction to: Sustainability Science (2021) 16:489-501 https://doi.org/10.1007/s11625-021-00930-1}

The article "Beyond Japanese NDC: energy and macroeconomic transitions towards 2050 in emission pathways with multiple ambition levels", written by Diego Silva Herran and Shinichiro Fujimori, was originally published Online First without Open Access. After publication in volume 16, issue 2, page 489-501 the author decided to opt for Open Choice and to make the article an Open Access publication. Therefore, the copyright of the article has been changed to () The Author(s) 2021 and the article is forthwith distributed under the terms of the Creative Commons Attribution 4.0 International License, which permits use, sharing, adaptation, distribution and reproduction in any medium or format, as long as you give appropriate credit to the original author(s) and the source, provide a link to the Creative Commons license, and indicate if changes were made. The images or other third party material in this article are included in the article's Creative Commons licence, unless indicated otherwise in a credit line to the material. If material is not included in the article's Creative Commons licence and your intended use is not permitted by statutory regulation or exceeds the permitted use, you will need to obtain permission directly from the copyright holder. To view a copy of this licence, visit http://creativecommons.org/licenses/by/4.0.

The original article was updated.

Open Access This article is licensed under a Creative Commons Attribution 4.0 International License, which permits use, sharing, adaptation, distribution and reproduction in any medium or format, as long as you give appropriate credit to the original author(s) and the source, provide a link to the Creative Commons licence, and indicate if changes were made. The images or other third party material in this article are included in the article's Creative Commons licence, unless indicated otherwise in a credit line to the material. If material is not included in the article's Creative Commons licence and your intended use is not permitted by statutory regulation or exceeds the permitted use, you will need to obtain permission directly from the copyright holder. To view a copy of this licence, visit http://creativecommons.org/licenses/by/4.0/.

Publisher's Note Springer Nature remains neutral with regard to jurisdictional claims in published maps and institutional affiliations.

The original article can be found online at https://doi.org/10.1007/ s11625-021-00930-1.

Diego Silva Herran

silva.diego@nies.go.jp; diego_silva_h@yahoo.com

1 National Institute for Environmental Studies (NIES), 16-2 Onogawa, Tsukuba, Ibaraki 305-8506, Japan

2 Institute for Global Environmental Strategies (IGES), Hayama, Japan

3 Graduate School of Engineering, Kyoto University, Kyoto city, Japan

4 International Institute for Applied Systems Analysis (IIASA) Laxenburg, Laxenburg, Austria 